\title{
INFLUENCE OF SOIL CULTIVATION TECHNOLOGIES AND FERTILISATION ON PRODUCTIVITY AND ENERGY PRODUCTION OF ARABLE CROPS
}

\author{
ŠTEFAN ŽÁK ${ }^{1}$, MILAN MACÁK², ROMAN HAŠANA ${ }^{1}$ \\ ${ }^{1}$ Plant Production Research Center Piešt'any \\ ${ }^{2}$ Slovak University of Agriculture in Nitra
}

ŽÁK, Š. - MACÁK, M. - HAŠANA, R.: Influence of soil cultivation technologies and fertilisation on productivity and energy production of arable crops. Agriculture (Pol'nohospodárstvo), vol. 58, 2012, no. 1, pp. $25-33$.

\begin{abstract}
The influence of three soil tillage technologies and two fertilisation levels on a productivity of crops and biomass for energy use, expressed in yield, cereal units (CU), energy acquired and indicative price of energy per hectare was evaluated at the experimental fields of Research Institute of Plant Production in Piešt'any during 2007-2009. The highest yield of dry matter has been identified for maize for silage $19.41 \mathrm{t} / \mathrm{ha}$, followed by winter oilseed rape $15.77 \mathrm{t} / \mathrm{ha}$, triticale $15.39 \mathrm{t} / \mathrm{ha}$ and winter wheat $14.08 \mathrm{t} / \mathrm{ha}$. Conventional tillage created soil condition for higher yield of dry matter in an average $17.92 \mathrm{t} / \mathrm{ha}$, followed by minimum soil tillage $16.27 \mathrm{t} / \mathrm{ha}$ and no-till-age technology $14.3 \mathrm{t} /$ ha. Nitrogen-based fertilisation $\left(\mathrm{N}_{120}\right)$ has ensured a significantly higher yield of dry matter and a higher
\end{abstract}

price of acquired energy $€ 491.1$ compared with $€ 462.1$ of zeronitrogen fertilisation. The highest yield of cereal units has been identified for maize for silage $9.01 \mathrm{CU}$, followed by winter wheat 5.21 CU, triticale 4.70 CU and winter oilseed rape 4.55 $\mathrm{CU}$. Energy of maize for silage has been calculated from biogas, winter oilseed rape from rape methyl ester, straw and crop residues, and for winter wheat and triticale from ethanol and straw. Average energy storage in plant biomass of crop rotation was $222.93 \mathrm{GJ} / \mathrm{ha}$. The highest amount of energy acquired has been identified for winter oilseed rape $342.80 \mathrm{GJ} / \mathrm{ha}$, followed by maize for silage with $236.99 \mathrm{GJ} / \mathrm{ha}$, winter triticale $159.39 \mathrm{GJ} / \mathrm{ha}$ and winter wheat $152.52 \mathrm{GJ} / \mathrm{ha}$.

Key words: crop rotation, productivity, arable crops, energy crops, soil cultivation, fertilisation

Development of environmentally sound technologies is focused on effective use of fertilisers and suitable tillage technologies. These two factors are also important for optimising energy production from biomass on arable land. Biomass has always been a major source of energy for mankind and is presently estimated to contribute about $10-14 \%$ of the world's energy supply (McKendry 2002). Beyond its agricultural and food-processing use, biomass is also used as an excellent fuel. Biochemical and thermo chemical conversion technologies can convert $\mathrm{CO}_{2}$ neutral biomass feedstock into carbon containing biofuels such as biodiesel, dimethyl esters to hydrogen (Cannell 2003; Prasertsana \& Sajjakulnukit 2006).

Energy crops currently contribute a relatively small proportion to the total energy produced from biomass each year, but the proportion is set to grow over the next few decades (Sims et al. 2006). Today, the biggest amounts of fuel ethanol (bio ethanol) are produced from sugar-beet (Brazil) or maize (USA). However, it is also possible to use other amylaceous crop-plants (barley, oat, rice, wheat, rye, potato, sorghum) and agricultural residues as straw from wheat, rye, oat, barley and rice (Kim \& Dale 2004).

Some of the more common energy crops related to this research are listed below. For example, oil crops are as follows: oilseed rape, linseed, field mustard, hemp, sunflower, safflower, castor oil, olive, palm, coconut and groundnut. Vegetable oils can be used directly as heating fuels or refined to transport biofuels

Ing. Štefan Žák, PhD., Ing. Roman Hašana, PhD., Plant Production Research Center Piešt’any - Research Institute of Plant Production Piešt’any, 92168 Piešt’any, Bratislavská cesta 122, Slovak Republic. E-mail: zak@vurv.sk

Doc. Dr. Ing. Milan Macák, Slovak University of Agriculture in Nitra, Tr. A. Hlinku 2, 94976 Nitra, Slovak Republic. E-mail:milan.macak@uniag.sk 
such as biodiesel esters. The grain of cereals (e.g. barley, wheat, oats, maize and rye) can be used to produce ethanol and the straw can be used as a solid fuel. They can also be grown and harvested as a whole crop (grain plus straw) before the grain has ripened and used as a solid fuel or for biogas production feedstock. Solid energy crops (e.g. whole crop maize, cardoon, sorghum, kenaf, reed canary grass and short rotation coppice willow). These crops can be utilised whole to produce heat and electricity directly through combustion or indirectly through conversion for use as biofuels like methanol and ethanol (Vilček 2003; Otepka \& Haban 2006; Sims et al. 2006; Otepka et al. 2011).

Cereals like rye, triticale, barley, maize and alfalfa show relatively low values of greenhouse gas emissions, and cumulated energy demand whereas hemp and Jerusalem artichoke have a considerable worse balance (Plöchl et al. 2009). Cultivation of wheat, triticale and rye for energy purposes had been earlier investigated also by Mikulíková et al. (2008).

Slovak agriculture can devote a certain amount of secondary agricultural soil to a special-purpose cultivation of green biomass for energy production either in the form of green plants for biogas (maize, cereals, pulses, etc.) or for a subsequent combined energy and heat production. From a total area of 370 thousands hectares of agricultural soil, 100,000 hectares has been thought over as a feasible area under cultivation for energy plantation of phytomass and dendromass.

The aim of the present research was to assess the influence of the field crops, soil cultivation and nitrogen fertilisation on productivity of crops and level of alternative energy use.

\section{MATERIAL AND METHODS}

The field experiment was carried out in 2007-2009 on Luvi-Haplic Chernozem in Plant Production Research Center Piešt'any - Research Station in Borovce. The experimental site is located in the maize-barley growing region in Western Slovakia (E 17 ${ }^{\circ} 75^{\prime}$, $\mathrm{N} 48^{\circ} 58^{\prime}$ ) with an altitude of $167 \mathrm{~m}$ above MSL (Mean Sea Level). The location has continental climate with an average annual temperature of $9.09^{\circ} \mathrm{C}$ an average annual precipitation of $544.9 \mathrm{~mm}$. The main soil type is a Luvi-Haplic Chernozem on carbonate loess with loamy to clay-loamy texture with a $\mathrm{pH}$ of 5.6-7.2 and medium humus content of $1.8 \%-2.0 \%, 187-234 \mathrm{mg} / \mathrm{kg}$ available $\mathrm{P}$ (according to Egner), $173-219 \mathrm{mg} / \mathrm{kg}$ available K (according to Schachtschabel) and $255-307 \mathrm{mg} / \mathrm{kg}$ available Mg (Mehlich II).

\section{Evaluated factors of the field experiment:}

- Factor A (crop-plant): a1 - winter triticale, a2 maize for silage, a3 - winter wheat, a4 - winter oilseed rape;

- Factor B (soil cultivation): b1 - direct sowing (no-tillage), b2 - minimum-tillage (disk tillage), b3 - conventional tillage (mouldboard ploughing);

- Factor $\mathrm{C}$ (nitrogen fertilisation): $\mathrm{c} 1=\mathrm{N}_{0}=$ unfertilised; $\mathrm{c} 2=\mathrm{N}_{120}=120 \mathrm{~kg} / \mathrm{ha}$ of nitrogen;

- Factor D (years): d1 = 2006/2007; d2 = 2007/2008; d $3=2008 / 2009$.

There are 48 treatment combinations and 96 plots sized $19.0 \mathrm{~m} \times 1.5 \mathrm{~m}=28.5 \mathrm{~m}^{2}$ included in the experiment. The experimental design was a randomised complete block in a split-plot arrangement with two replicates of four-course crop rotation. Crops were the main plots, the soil tillage technologies were the subplots, with two levels of fertilisation (Table 1). Common management practices for crop protection, processing and harvesting were used.

We evaluated the productivity of crops using two indicators. Crop of dry matter according to plant analysis; cereal units (CU) according Čvančara (1967) using coefficients as follows: for winter wheat and triticale 1.0, winter oilseed rape 2.0, maize for silage 0.15 . Term cereal units is used to express the contribution that crops make to the nutrition of monogastric beings. Energy production from evaluated crops was calculated according to the amount of acquired energy: energy of maize for silage has been calculated from methane $\left(1 \mathrm{~m}^{3}=35.8 \mathrm{GJ}\right)$, amount of methane was calculated from biogas production (from one kg of dry matter of maize biomass $680 \mathrm{dm}^{3}$ biogas is obtained), of winter oilseed rape from biodiesel-rape methyl ester, $1 \mathrm{t}$ rape methyle ester $=33.997 \mathrm{GJ}$ and straw $1 \mathrm{t}=17.5 \mathrm{GJ}$, and for winter wheat and triticale from ethanol $1 \mathrm{t}=25.121 \mathrm{GJ}$ and straw $1 \mathrm{t}=15.5 \mathrm{GJ}$ (Opath \& Horbaj 2004; Sims et al. 2006). Gain of energy was expressed in indicative price in Euro $(€)$. Indicative price of $1 \mathrm{GJ}$ of energy from biomass has been balanced at the level of $€ 2.15$ (own calculation for 2009 year). The data were statistically evaluated 
by an analysis of variance using the Statgraphics plus procedure and for comparing treatment group means Fisher's LSD (Least Significance Difference) method was used.

\section{RESULTS AND DISCUSSION}

The weather was diverse during 2006-2009. As a long-term average annual temperature for a period of 1971-2000 was $9.1^{\circ} \mathrm{C}$, the year 2006 was considered warm, but years 2007, 2008 and 2009 was considered exceptionally warm (Figure 1). The temperature during a vegetation period (April - September) ranged from $17.05^{\circ} \mathrm{C}$ (year 2007) to $18.6^{\circ} \mathrm{C}$ (year 2009), while in 2007 the vegetation period was warm, in years 2006 and 2008 very warm and in 2009 exceptionally warm. During a winter half year (October-March), the temperature varied between $2.9^{\circ} \mathrm{C}$ (year 2006) and $4.7^{\circ} \mathrm{C}$ (year 2008). The temperature in a winter half year
2006 was standard, in years 2007 and 2008 exceptionally warm and in 2009 warm. Long-term average temperature in a period $1971-2000$ was $15.6^{\circ} \mathrm{C}$ for a vegetation period and $2.5^{\circ} \mathrm{C}$ for a winter period.

Average annual precipitation ranged from $532.1 \mathrm{~mm}$ (year 2008) to $599.1 \mathrm{~mm}$ (year 2007). Average annual precipitation amount of a long-term average was 544.9 $\mathrm{mm}$, and all the years were standard humid conditions. Precipitation during a vegetation period (April-September) ranged from $254.2 \mathrm{~mm}$ (year 2009) to 351.6 $\mathrm{mm}$ (year 2007), for all the years a precipitation during a vegetation period was standard. Precipitation during a winter period (October-March) ranged from 187.5 $\mathrm{mm}$ (year 2008) to $329.7 \mathrm{~mm}$ (year 2009), a precipitation amount of winter period was standard in years 2006, 2007 and 2008, but very humid in 2009.

Because of a different yield potential of individual crops, the evaluation based on a crop of dry matter ( $\mathrm{t} / \mathrm{ha}$ ), cereal units, energy acquired (GJ/ha) and indicative price of energy $(€)$ has been applied in order to inte-

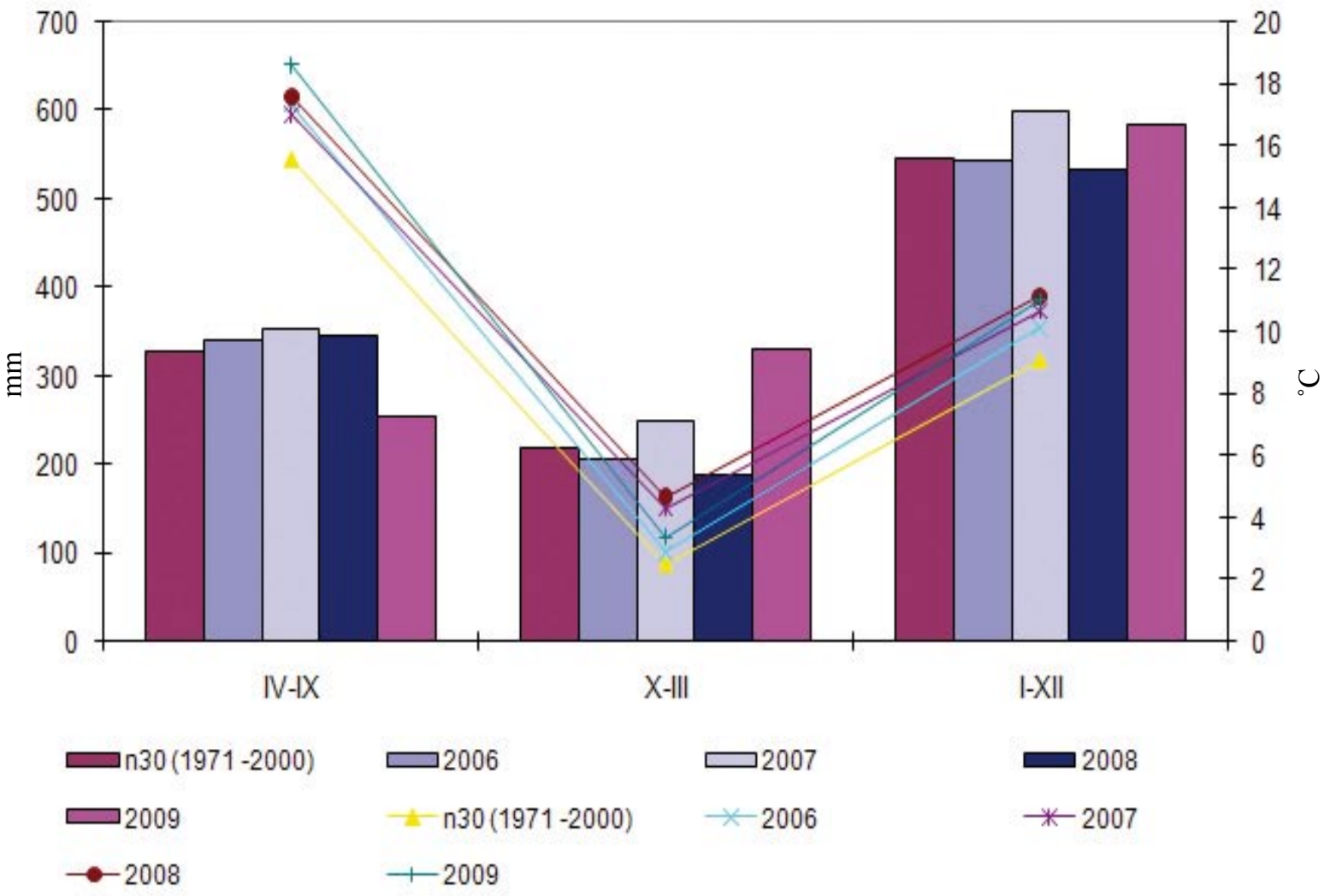

Figure 1. Weather condition of experimental site during 2006-2009 in Borovce 
grate productivity of crops and other factors compared. Statistical evaluation is presented in Tables 2 and 3.

Yield of dry matter, cereals units and energy acquired were influenced by the year, crops, tillage technology and different fertilisation (Table 2). Significant interaction between year and crop, and between year and tillage technology indicates that the year conditions significantly affected all evaluated sources of variation except fertilisation.

Yield of "crop dry matter" as an indicator of crops productivity is documented in Table 3. During 20072009 , a crop of dry matter reached a yield of $16.16 \mathrm{t} / \mathrm{ha}$ as an average of the experiment. Significant differences were observed between the years. While in 2008 yield of dry matter was $17.40 \mathrm{t} / \mathrm{ha}$. In 2007 and 2009 yield of dry matter was only $15.88 \mathrm{t} / \mathrm{ha}$ or 15.21 , respectively. Concerning crops, the significantly highest yield of dry matter has been identified for maize for silage $19.41 \mathrm{t} / \mathrm{ha}$ with comparison to winter oilseed rape (15.77 t/ha) and triticale (15.39 $\mathrm{t} / \mathrm{ha})$. Winter wheat has statistically the lowest yield at the average level of $14.08 \mathrm{t} / \mathrm{ha}$.

There is an alternative technology of traditional agricultural soil processing, so called minimising cultivation, which is based on reduction of some operating processes used in common. It is possible to perform this technology only in particular soil conditions (Vilček \& Kováč 2011). In our experiment, the highest yield of dry matter has been identified for use of conventional till-

$\mathrm{T}$ a b 1 e 1

Fertilisation treatments of field crops during 2007-2009

\begin{tabular}{|c|c|c|}
\hline Crop & $\mathrm{N}_{0}$ (lower level) & $\mathrm{N}_{120}$ (higher level) \\
\hline Winter triticale & $\mathrm{N}_{0} \mathrm{PK}$ & $\mathrm{N}_{120} \mathrm{P}_{30} \mathrm{~K}_{90}$ \\
\hline Maize for silage & $\mathrm{N}_{0} \mathrm{PK}$ & $\mathrm{N}_{120} \mathrm{P}_{45} \mathrm{~K}_{110}$ \\
\hline Winter wheat & $\mathrm{N}_{0} \mathrm{PK}$ & $\mathrm{N}_{120} \mathrm{P}_{30} \mathrm{~K}_{80}$ \\
\hline Winter oilseed rape & $\mathrm{N}_{0} \mathrm{PK}$ & $\mathrm{N}_{120} \mathrm{P}_{40} \mathrm{~K}_{150}$ \\
\hline
\end{tabular}

$\mathrm{T}$ a b 1 e 2

F statistics from ANOVA for yield of dry matter, unit grain equivalent and energy acquired of crop rotation for the years 2007-2009

\begin{tabular}{|c|c|c|c|c|c|c|c|}
\hline \multirow{2}{*}{ Source of variability } & \multirow{2}{*}{ d.f. } & \multicolumn{2}{|c|}{ Yield of dry matter [t/ha] } & \multicolumn{2}{|c|}{ Cereal units } & \multicolumn{2}{|c|}{ Energy acquired [GJ/ha] } \\
\hline & & Sum of squares & $\mathrm{F}$ & Sum of squares & $\mathrm{F}$ & Sum of squares & $\mathrm{F}$ \\
\hline Year $(Y)$ & 2 & 241.11 & $20.37^{++}$ & 179.57 & $98.25^{++}$ & $190,086.4$ & $119.56^{++}$ \\
\hline Crop (C) & 3 & $1,123.46$ & $63.27^{++}$ & 964.28 & $351.73^{++}$ & $1,696,389.1$ & $711.33^{++}$ \\
\hline Tillage (T) & 2 & 629.88 & $53.21^{++}$ & 59.00 & $32.28^{++}$ & $134,666.4$ & $84.70^{++}$ \\
\hline Fertilization $(\mathrm{F})$ & 1 & 92.93 & $15.70^{++}$ & 42.33 & $46.33^{++}$ & $23,241.5$ & $29.23^{++}$ \\
\hline $\mathrm{Y} \times \mathrm{C}$ & 6 & $2,959.30$ & $78.00^{++}$ & 503.76 & $82.56^{++}$ & $1,180,472.8$ & $218.00^{++}$ \\
\hline $\mathrm{Y} \times \mathrm{T}$ & 4 & 245.05 & $9.69^{++}$ & 2.69 & 0.66 & $26,201.7$ & 725.00 \\
\hline $\mathrm{Y} \times \mathrm{F}$ & 2 & 25.03 & $2.12^{-}$ & 2.84 & $1.55^{-}$ & 113.3 & $0.07^{-}$ \\
\hline $\mathrm{C} \times \mathrm{T}$ & 6 & 708.25 & $18.67^{++}$ & 32.95 & $5.40^{++}$ & $131,216.0$ & $24.23^{++}$ \\
\hline Residual & 196 & $1,411.62$ & - & 231.85 & - & $205,764.1$ & - \\
\hline Total & 287 & $7,847.51$ & - & $2,054.90$ & - & $3,643,232.6$ & - \\
\hline
\end{tabular}

${ }^{++}$Significant at $P<0.01$ probability level 
age (CT) technology of soil cultivation $17.92 \mathrm{t} / \mathrm{ha}$, followed by minimum tillage technology (MTT) $16.27 \mathrm{t} / \mathrm{ha}$ and the lowest yield of dry matter has been identified for a non-tillage technology (NTT) - $14.30 \mathrm{t} / \mathrm{ha}$. Therefore, use of CT has significantly higher yield of dry matter than use of MTT and NTT, while use of MTT has significantly higher yield of dry matter than use of NTT. Concerning evaluated crops and soil cultivation technology (Table 4), the higher yield of dry matter of winter oilseed rape was under CT $-18.31 \mathrm{t} / \mathrm{ha}$ with comparisons to $13.85 \mathrm{t} / \mathrm{ha}$ and $15.14 \mathrm{t} / \mathrm{ha}$ in NTT and MTT. Similarly, maize for silage under CT reached $22.86 \mathrm{t} / \mathrm{ha}$ with comparison to $14.13 \mathrm{t} / \mathrm{ha}$ in NTT. Evaluated cereals have smaller differences be- tween technology than maize and winter oilseed rape. These results are supported also by research of Hnát (2009) on eastern Slovakia with the evaluation of the same tillage treatments on yield of maize. CT supports the significantly higher yield of grain followed by the MTT and the lowest yield for NTT system was determined. Similarly Candráková et al. (2008) found out the highest maize yield in $\mathrm{CT}$ and shallow tillage (up to $150 \mathrm{~mm}$ ) compared with disking. In winter wheat, they have not found significant differences between tillage treatments. Kotorová et al. (2010) also found that the tillage systems decreased the yield of grain maize in order $\mathrm{CT}>\mathrm{MTT}>\mathrm{NTT}$.

$\mathrm{T}$ a $\mathrm{b} 1$ e 3

Average value of indicators of evaluated crops under different soil cultivation technology and fertilization level during 2007-2009

\begin{tabular}{|c|c|c|c|c|}
\hline Indicator & $\begin{array}{l}\text { Dry matter } \\
{[\mathrm{t} / \mathrm{ha}]}\end{array}$ & Cereal units & $\begin{array}{c}\text { Energy acquired } \\
{[\mathrm{GJ} / \mathrm{ha}]}\end{array}$ & $\begin{array}{c}\text { Indicative price } \\
\text { of energy per } \\
\text { ha }[€]\end{array}$ \\
\hline Total average of the experiment & 16.16 & 5.87 & 222.93 & 479.30 \\
\hline \multicolumn{5}{|c|}{ Year } \\
\hline 2007 & $15.88^{\mathrm{b}}$ & $5.27^{\mathrm{a}}$ & $243.98^{b}$ & $524.50^{\mathrm{b}}$ \\
\hline 2008 & $17.40^{\mathrm{c}}$ & $6.98^{\mathrm{b}}$ & $338.04^{c}$ & $509.90^{\mathrm{b}}$ \\
\hline 2009 & $15.20^{\mathrm{a}}$ & $5.35^{\mathrm{a}}$ & $186.76^{\mathrm{a}}$ & $395.90^{\mathrm{a}}$ \\
\hline $\mathrm{LSD}_{0.01}$ & 0.66 & 0.27 & 8.06 & 18.75 \\
\hline \multicolumn{5}{|c|}{ Crops } \\
\hline Winter oilseed rape & $15.77^{\mathrm{b}}$ & $4.55^{\mathrm{a}}$ & $342.80^{\mathrm{c}}$ & $737.00^{\mathrm{c}}$ \\
\hline Winter triticale & $15.39^{\mathrm{b}}$ & $4.70^{\mathrm{a}}$ & $159.39^{\mathrm{a}}$ & $342.70^{\mathrm{a}}$ \\
\hline Maize for silage & $19.41^{\mathrm{c}}$ & $9.01^{\mathrm{c}}$ & $236.99^{b}$ & $509.50^{\mathrm{b}}$ \\
\hline Winter wheat & $14.08^{\mathrm{a}}$ & $5.21^{\mathrm{b}}$ & $152.52^{\mathrm{a}}$ & $327.90^{\mathrm{a}}$ \\
\hline $\mathrm{LSD}_{0.01}$ & 1.05 & 0.41 & 12.22 & 21.95 \\
\hline \multicolumn{5}{|c|}{ Soil cultivation technology } \\
\hline No-tillage technology (NTT) & $14.30^{\mathrm{a}}$ & $5.33^{\mathrm{a}}$ & $196.53^{\mathrm{a}}$ & $422.50^{\mathrm{a}}$ \\
\hline Minimum-tillage technology (MTT) & $16.27^{\mathrm{b}}$ & $5.84^{\mathrm{b}}$ & $222.75^{\mathrm{b}}$ & $478.90^{\mathrm{b}}$ \\
\hline Conventional technology (CT) & $17.92^{\mathrm{c}}$ & $6.43^{\mathrm{c}}$ & $249.50^{c}$ & $536.40^{\mathrm{c}}$ \\
\hline $\mathrm{LSD}_{0.01}$ & 0.91 & 0.35 & 10.58 & 19.01 \\
\hline \multicolumn{5}{|c|}{ Fertilisation } \\
\hline Lower level $\left(\mathrm{N}_{0}\right)$ & $15.59^{\mathrm{a}}$ & $5.48^{\mathrm{a}}$ & $214.94^{\mathrm{a}}$ & $462.10^{\mathrm{a}}$ \\
\hline Higher level $\left(\mathrm{N}_{120}\right)$ & $16.73^{b}$ & $6.25^{\mathrm{b}}$ & $228.40^{\mathrm{b}}$ & $491.10^{\mathrm{b}}$ \\
\hline $\mathrm{LSD}_{0.01}$ & 0.74 & 0.29 & 8.64 & 15.52 \\
\hline
\end{tabular}

The means followed by the same letter are not significantly different at $P_{0.01}<$ probability level 
Nitrogen-based fertilisation $\left(\mathrm{N}_{120}\right)$ has guaranteed a significantly higher yield of dry matter with comparison to $\mathrm{N}_{0}$. Evaluated crops response differently to the conditions of years or soil cultivation technologies as indicates highly significant interactions: crop $\times$ year and crop $\times$ soil cultivation technology (Table 2 ).

Comparison of crop productivity (Table 3 ) has been performed by means of cereal units. The average of the experiment was 5.87 CU in a period 2007-2009. A highly significant difference has been identified between the most favourable year 2008 (9.01 CU) and 2007 (4.70 CU) or 2009 (CU 5.21 CU).

The highest yield of cereal units has been identified for maize for silage 9.01 CU, followed by winter wheat - 5.21 CU, triticale - 4.70 CU, winter oilseed rape 4.55 CU. Maize for silage has been proved to be significantly more productive than winter wheat, triticale and winter oilseed rape, while the yield of cereal units of winter oilseed rape and triticale has been significantly lower than winter wheat. The significantly highest yield of cereal units has been identified for a use of CT of soil cultivation $6.43 \mathrm{CU}$, followed by MTT $-5.84 \mathrm{CU}$ and the lowest yield of cereal units was un- der NTT - 5.33 CU. In all evaluated crops (Table 4) the highest yield expressed in CU was under CT. For maize for silage MTT (disk cultivation) is comparable with conventional mouldboard ploughing.

Nitrogen-based fertilisation $\left(\mathrm{N}_{120}\right)$ has guaranteed a highly significant increase in yield of cereal units (6.25 CU) with comparison to zero nitrogen (5.48 $\mathrm{CU})$. From an environmental point of view we have to take into consideration also energy inputs (Pospišil \& Ržonca 2010) and environmental load from nitrogen fertilisation (Fazekašová et al. 2011). Užík and Žofajová (2009) also found that effect of $\mathrm{N}$ on grain yield of different cultivars of winter wheat was significant, but little effective on the fertile soil environment. The highest average grain yield ( $8.76 \mathrm{t} / \mathrm{ha})$ was higher only by $4.6 \%$ in the treatment $\mathrm{N}_{120}$ compared with zero treatment $\mathrm{N}_{0}$ in the favourable year 2005. In the less favourable year 2006, increase of grain yield at $\mathrm{N}_{120}$ rate compared with $\mathrm{N}_{0}$ was higher $(116.3 \%)$.

Interactions year $\times$ crop and crop $\times$ technology of soil cultivation has highly significant effect on the variability of cereal units production.

$\mathrm{T}$ a b 1 e 4

Indicators value for evaluated crops under different cultivation technologies 2007-2009 in Borovce

\begin{tabular}{|c|c|c|c|c|}
\hline Interactions & $\begin{array}{c}\text { Dry matter } \\
{[\mathrm{t} / \mathrm{ha}]}\end{array}$ & Cereal units & $\begin{array}{c}\text { Energy acquired } \\
{[\mathrm{GJ} / \mathrm{ha}]}\end{array}$ & $\begin{array}{c}\text { Indicative price } \\
\text { of energy per } \\
\text { ha }[€]\end{array}$ \\
\hline \multicolumn{5}{|l|}{ Crops $\times$ soil cultivation technology } \\
\hline Oilseed rape - no-tillage technology & 13.85 & 4.59 & 300.89 & 646.9 \\
\hline Oilseed rape - minimum-tillage tech. & 15.14 & 4.12 & 332.98 & 715.9 \\
\hline Oilseed rape - conventional tillage & 18.31 & 4.95 & 394.53 & 848.2 \\
\hline Triticale - no-tillage technology & 14.72 & 4.24 & 156.64 & 336.8 \\
\hline Triticale - minimum-tillage technology & 15.01 & 4.48 & 150.96 & 324.6 \\
\hline Triticale - conventional tillage & 16.44 & 5.38 & 170.58 & 366.7 \\
\hline Maize - no-tillage technology & 14.13 & 7.78 & 173.51 & 373.0 \\
\hline Maize - minimum-tillage technology & 21.24 & 9.39 & 256.69 & 551.9 \\
\hline Maize - conventional tillage & 22.86 & 9.85 & 280.77 & 603.7 \\
\hline Wheat - no-tillage technology & 14.51 & 4.69 & 155.08 & 333.4 \\
\hline Wheat - minimum-tillage technology & 13.68 & 5.37 & 150.37 & 323.3 \\
\hline Wheat - conventional tillage & 14.06 & 5.56 & 152.11 & 327.0 \\
\hline
\end{tabular}

Indicative price of 1 GJ of energy from biomass $€ 2.15$ (own calculation according 2009 year level). 
Growing crops for energy production have been compared on the basis of energy acquired (in GJ/ha). During 2007-2009, average energy of the experiment at the level of $222.93 \mathrm{GJ} /$ ha was acquired. In the most favourable year condition (in 2008), the significant energy acquired in plant biomass has been noted (Table 3 ). The highest amount of energy acquired (in GJ/ha) has been identified for winter oilseed rape $-342.80 \mathrm{GJ} / \mathrm{ha}$, followed by maize for silage with $236.99 \mathrm{GJ} / \mathrm{ha}$. Triticale with $159.39 \mathrm{GJ} / \mathrm{ha}$ and winter wheat with $152.52 \mathrm{GJ} / \mathrm{ha}$ acquired significantly less amount of energy with comparison to winter oilseed rape and maize for silage. Composition of energy has been as follow: winter triticale $-35 \%$ composed of ethanol and $65 \%$ of straw, maize for silage $100 \%$ of biogas, winter wheat $-40 \%$ of ethanol and $60 \%$ of straw, winter oilseed rape $-10 \%$ of biodiesel and $90 \%$ of straw and crop residues. Values of the indicators are found in Table 5. These results are higher than energy value of the crop obtained by energy balance evaluation due to full accounting of storage energy of biomass. Pospišil and Ržonca (2010) stated the energy value of winter wheat yields in interval 96.4-107.6 GJ/ha and for maize in interval 149.4$177.6 \mathrm{GJ} / \mathrm{ha}$ by using coefficient of $17.64 \mathrm{GJ} / \mathrm{mg}$ of dry matter of main product. Shäfer (2005) mentioned that the process energy for crop production may be attrib- uted to seed, straw and roots.

The highest amount of energy acquired (in GJ/ha) has been identified for use of conventional technology of soil cultivation (CT) - $252.59 \mathrm{GJ} / \mathrm{ha}$, followed by MTT $-222.28 \mathrm{GJ} /$ ha and the lowest amount of energy acquired has been identified for NTT - $196.53 \mathrm{GJ} / \mathrm{ha}$. Use of CT has therefore guaranteed a highly significant increment in the amount of energy acquired (in $\mathrm{GJ} / \mathrm{ha}$ ) compared with use of MTT or NTT. Use of MTT has guaranteed a highly significant increment in the amount of energy acquired compared with use of NTT. Nitrogen-based fertilisation $\left(\mathrm{N}_{120}\right)$ has supported a highly significant increase in the amount of energy acquired (in $\mathrm{GJ} / \mathrm{ha}$ ), but net gain of energy was only $13.46 \mathrm{GJ} / \mathrm{ha}$.

Only interactions: year $\times$ crop, and crop $\times$ tillage technology have been highly significant.

As an economic indicator, indicative price of acquired energy in plant biomass was calculated. During 2007-2009, indicative price of storage energy of whole crop rotation was balanced at $€ 479$.3. The highest indicative price of energy has been identified for winter oilseed rape (€737.0) followed by maize for silage (€509.5), winter triticale (€342.7) and winter wheat (€327.9). The highest indicative price of energy acquired was reached at CT - $€ 536.4$ followed by MTT

$\mathrm{T}$ a b 1 e 5

The energy composition, calculated from different sources of energy crops [GJ/ha] growing in crop rotation pattern during 2007-2009 in Borovce

\begin{tabular}{|c|c|c|c|c|c|c|c|c|c|c|c|}
\hline \multirow{2}{*}{ Experiment } & \multicolumn{3}{|c|}{ Winter triticale } & \multirow{2}{*}{$\begin{array}{l}\text { Maize } \\
\text { for } \\
\text { silage }\end{array}$} & \multicolumn{3}{|c|}{ Winter wheat } & \multicolumn{3}{|c|}{ Winter oilseed rape } & \multirow{2}{*}{$\begin{array}{c}\begin{array}{c}\text { Energy } \\
\text { of crop } \\
\text { rotation }\end{array} \\
\text { Total }\end{array}$} \\
\hline & Ethanol & Straw & Total & & Ethanol & Straw & Total & $\begin{array}{c}\text { Bio } \\
\text { diesel }\end{array}$ & $\begin{array}{c}\text { Straw } \\
\text { and crop } \\
\text { residues }\end{array}$ & Total & \\
\hline Average & 56.0 & 103.4 & 159.4 & 237.0 & 62.6 & 90.0 & 152.5 & 30.8 & 312.3 & 342.8 & 891.7 \\
\hline NTT & 51.3 & 105.3 & 156.6 & 173.5 & 57.8 & 97.3 & 155.1 & 31.1 & 270.2 & 300.9 & 786.1 \\
\hline MTT & 52.8 & 98.2 & 151.0 & 256.7 & 63.2 & 87.2 & 150.4 & 28.1 & 305.3 & 333.0 & 891.0 \\
\hline CTT & 63.9 & 106.8 & 170.6 & 280.8 & 66.7 & 85.4 & 152.1 & 33.2 & 361.3 & 394.5 & 998.0 \\
\hline $\mathrm{N}_{0}$ & 51.9 & 96.8 & 148.7 & 224.1 & 55.6 & 89.6 & 145.3 & 29.3 & 308.6 & 337.7 & 855.8 \\
\hline $\mathrm{N}_{120}$ & 60.0 & 110.1 & 170.1 & 249.9 & 69.5 & 90.3 & 159.8 & 32.3 & 315.9 & 347.9 & 927.6 \\
\hline
\end{tabular}

Where: average - average of the experiment, NTT - no-tillage technology, MTT - minimum tillage technology, CTT -conventional tillage technology, $\mathrm{N}_{0}$ - lower fertilization level, $\mathrm{N}_{120}-$ higher fertilization level 
- €478.9 and for NTT only €422.5. Nitrogen-based fertilisation $\left(\mathrm{N}_{120}\right)$ has guaranteed a highly significant increase in indicative price of energy acquired (€498.6) compared with $€ 460.0$ of zero-nitrogen fertilisation.

All forms of bioenergy when substituted for fossil fuels will directly reduce $\mathrm{CO}_{2}$ emissions. Therefore, a combination of energy crop production with carbon sink and offset credits can result in maximum benefits from carbon mitigation strategies. This can be achieved by planting energy crops into previously arable or pasture land, which will lead to an increase in the average carbon stock on that land, while also yielding a source of biomass.

\section{CONCLUSION}

The results achieved during 2007-2009, on an experimental basis of Plant Production Research Center Piešt'any in Borovce imply that all the crop-plants included in the crop rotation have been responsive to soil cultivation and to nitrogen-based fertilisation, that is also suggested by the following findings:

CT and MTT with nitrogen-based fertilisation $\left(\mathrm{N}_{120}\right)$ create better conditions for higher yield parameters in comparison with NTT, evaluated by indicators of productivity - yield of dry matter, yield of cereal units and energy acquired. For bioenergy purposes the energy acquired indicator is recommended.

Maize for silage has proved to be significantly more productive than triticale winter wheat and winter oilseed rape expressed in CU (9.01) and yield of dry matter (19.41 t/ha).

Nitrogen-based fertilisation $\left(\mathrm{N}_{120}\right)$ has guaranteed a higher indicative price of energy (about €29) compared with zero-nitrogen fertilisation.

Energy crops are suitable to substitute fossil fuels as energy sources. Therefore, a substantial contribution can be achieved in the effort to mitigate the additional greenhouse effect.

Acknowledgement. The article is based on findings of a research and development assignment: 2006 UO 27/091 05 01/091 05 10-03-04, Solution to competitiveness and ecologisation of crop production in regions of Slovakia through systems of soil management and innovation of cultivation technologies".

\section{REFERENCES}

CANDRÁKOVÁ, E. - POSPIŠIL, R. - ONDREJČíKOVÁ, Z. 2008. Efficiency of fertilization and soil cultivation in crop rotation. In Journal of Central European Agriculture, vol. 9, 2008, no. 3, pp. 519-526.

CANNELL, M.G.R. 2003. Carbon sequestration and biomass energy offset: theoretical, potential and achievable capacities globally, in Europe and the UK. In Biomass and Bioenergy, vol. 44, 2003, pp. 97-116.

ČVANČARA, F. 1967. Zemédělská výroba v číslech, díl 1. [Crop production in figures. $1^{\text {st }}$ part]. Praha: SZN, 1967. $771 \mathrm{p}$.

FAZEKAŠOVÁ, D. - BOBULSKÁ, L. - MACKOVÁ, D. 2011. Biodiversity and environment quality in the conditions of ecological farming on soil. In Növénytérmeles, vol. 60, 2011, Suppl., pp. 427-430. DOI: 10.1556/Novenyterm.60.2011.Suppl.1

HNÁT, A. 2009. The dependence of grain maize yield (Zea mays L.) from different soil tillage and meteorological conditions. In Agriculture (Pol'nohospodárstvo), vol. 55, 2009 , no. 3, pp. 148-155.

KOTOROVÁ, D. - HNÁT, A. - DANILOVIČ, M. - ŠARIKOVÁ, D. - BALLA, P. 2010. Soil tillage in relation to soil properties and yields of crops. In Agriculture (Polnohospodárstvo), vol. 56, 2010, no. 3, pp. 67-75.

KIM, S. - DALE, B.E. 2004. Global potential bioethanol production from wasted crops and crop residues. In Biomass Bioenergie, vol. 26, 2004, no. 4, pp. 361-375.

McKENDRY, P. 2002. Energy production from biomass (part 1): overview of biomass. In Bioresource Technology, vol. 83, 2002, no. 1, pp. 37-46.

MIKULÍKOVÁ, D. - HORVÁThOVÁ, V. - ŽOFAJOVÁ, A. 2008. Obsah a zloženie škrobu v zrne pšenice raže a tritikale. In Chemické Listy, vol. 102, 2008, no. 9, pp. 822-828.

OPÁTH, R. - HORBAJ, P. 2004. Fytopalivo z ornej pôdy [Biofuel from arable land]. In Moderná mechanizácia $v$ pol'nohospodárstve, vol. 7, 2004, no. 2. pp. 30-31.

OTEPKA, P. - HABÁN, M. 2006. Biomass yield of basked willow (Salix viminalis L.) cultivated as energy plant in a long-term experiment. In Acta fytotechnica et zootechnica, vol. 9, 2006, no. 3, pp. 70-74.

OTEPKA, P. - HABÁN, M. - HABÁNOVÁ, M. 2011. Cultivation of fast-growing woody plant basket willow (Salix viminalis L.) and their bioremedial abilities while fertilized with wood ash. In Research Journal of Agricultural Science, vol. 43, 2011, no. 2, pp. 218-222.

POSPIŠIL, R. - RŽONCA, J. 2010. Influence of different soil tillage technologies on energy balance of crop rotation. In Agriculture (Polnohospodárstvo), vol. 56, 2010, no. 4, pp. 114-120

PLÖCHL, M. - HEIERMANN, M. - LINKE, B. - SCHELLE, H. 2009. Biogas Crops - Part II: Balance of Greenhouse Gas Emissions and Energy from Using Field Crops for Anaerobic Digestion. In Agricultural Engineering International: the CIGR Ejournal, vol. 9, 2009, Manuscript number 1086, pp. 1-11.

PRASERTSANA, S. - SAJJAKULNUKIT B. 2006. Biomass and biogas energy in Thailand: potential, opportunity and barriers. In Renewable Energy, vol. 31, 2006, pp. 599610. 
SIMS, R.E.H. - HASTINGS, A. - SCHLAMADINGER, B. TAYLOR, G. - SMITH, P. 2006. Energy crops: current status and future prospects. In Global Change Biology, vol. 12, 2006, pp. 2054-2076.

UŽÍK, M. - ŽOFAJOVÁ. A. 2009. Response of winter wheat cultivars to $\mathrm{N}$ fertilization in grain yields and its components. In Agriculture (Pol'nohospodárstvo), vol. 55, 2009, no. 4, pp.171-182.

VILČEK, J. 2003. Ekonomická efektívnost' pestovania plodín v závislosti od pôdnych predstavitelov [Cropping efficacy as influenced by soil representatives]. In Agriculture (Pol'nohospodárstvo), vol. 49, 2003, no. 6, pp. 269-273.
VILČEK, J. - KOVÁČ, K. 2011. Sites availability for minimalizing and soil-conservation tillage. In Agriculture (Polnohospodárstvo), vol. 57, 2011, no. 2, pp. 68-75. DOI: $10.2478 / \mathrm{v} 10207-011-0008-\mathrm{x}$

Received: July, $30^{\text {th }}, 2010$ 